\title{
MANAGEMENT OF ENDOCRINE DISEASE Pituitary tumour apoplexy
}

\author{
Cristina Capatina, Warrick Inder ${ }^{1,2}$, Niki Karavitaki ${ }^{3}$ and John A H Wass ${ }^{3}$ \\ Department of Endocrinology, Carol Davila University of Medicine and Pharmacy, Bucharest, Romania, \\ ${ }^{1}$ Department of Diabetes and Endocrinology, Princess Alexandra Hospital, Brisbane, Queensland, Australia, \\ ${ }^{2}$ Department of Diabetes and Endocrinology, School of Medicine, The University of Queensland, Brisbane, \\ Queensland, Australia and ${ }^{3}$ Department of Endocrinology, Oxford Centre for Diabetes, Endocrinology and \\ Metabolism, Churchill Hospital, Old Road, Headington, Oxford OX3 7LE, UK
}

Correspondence should be addressed to J A H Wass

Email

john.wass@noc.anglox.nhs.uk

\begin{abstract}
Pituitary tumour apoplexy (PA) is a rare clinical syndrome that occurs as a result of acute haemorrhage and/or infarction within a frequently undiagnosed pituitary tumour. The sudden enlargement of the pituitary mass undergoing PA is responsible for a wide range of acute symptoms/signs (severe headache, visual loss, diplopia, hypopituitarism, impaired consciousness) which, together with the radiological evidence of a pituitary lesion, establish the diagnosis. The optimal care of PA requires involvement of a multidisciplinary team including endocrinologist, neurosurgeon, neuroophthalmologist and the management strategy that depends on the clinical manifestations, as well as the presence of co-morbidities. Prompt surgical decompression is initially indicated in cases with severe or progressive impairment of the visual acuity or the visual fields or with altered mental state and leads to visual and neurological recovery in most of the patients. The patients with mild, stable clinical picture (including those with isolated ocular palsies) can be managed conservatively (support of fluid and electrolyte balance and stress doses of steroids in most cases) with favourable visual and neurological outcome. Frequent reassessment is mandatory because the clinical course can be unpredictable; if progression of symptoms occurs, later elective surgery is indicated and is beneficial, especially in terms of visual outcome. The endocrinological outcome is less favourable, irrespective of the treatment option, with many patients remaining on long-term replacement therapy. Despite the above guidelines, clear proof of optimal outcomes in the form of randomised controlled trials is lacking. Regrowth of the pituitary tumour years after a PA episode is possible and patients require long-term surveillance.
\end{abstract}

\section{Definition}

Pituitary tumour apoplexy (PA) is a rare clinical syndrome resulting from the rapid and often life-threatening expansion in the majority of cases of a pituitary tumour within the sella turcica, due to either haemorrhage or infarction.

The name of pituitary apoplexy was coined in 1950 (1); it depicts a constellation of severe, sudden-onset clinical manifestations (headache, visual impairment,

\footnotetext{
Invited Author's profile

John Wass is Professor of Endocrinology, Oxford University and was Head of the Department of Endocrinology at the Oxford Centre for Diabetes, Endocrinology and Metabolism, Churchill Hospital Oxford, UK until 2011. He is also Academic Vice President of the Royal College of Physicians in London. His research interests include all pituitary tumours, especially acromegaly, adrenal disease, angiogenesis in endocrinology, and the genetics of osteoporosis and thyroid disease. He has published over 350 articles in scientific journals and written many reviews and chapters in textbooks including the Oxford Textbook of Medicine and DeGroot's Textbook of Endocrinology. He has won a number of prizes including the Jubilee Prize of the Society for Endocrinology and the Distinguished Physician of the Year Award by the American Endocrine Society.
}

(c) 2015 European Society of Endocrinology Printed in Great Britain
Published by Bioscientifica Ltd. 
ophthalmoplegia) which, together with the evidence of a pituitary mass showing haemorrhage on imaging, define the classical PA episode (2). However, as the pathogenetic event implies the pituitary lesion (most frequently a pituitary tumour), the condition is more accurately described as pituitary tumour apoplexy.

The term subclinical pituitary tumour apoplexy $(3,4)$ was later applied for asymptomatic pituitary haemorrhage identified at surgery or during radiological investigation or at the pathological examination. However, PA is a clinical diagnosis and the term should be reserved only for the classical presentation. The latter is what has been discussed in detail.

\section{Epidemiological data}

The true incidence of this rare condition is difficult to determine because almost all the studies published to date are retrospective and in most reports PA represents the first manifestation of previously unknown pituitary pathology. In neurosurgical series, which suffer from selection bias, the incidence of PA is variably reported between 0.6 and $9.1 \%(2,5,6,7,8,9,10)$, while asymptomatic haemorrhage disclosed at the time of the surgery was identified in $7.5-14.8 \%(5,8,11)$.

In a large epidemiological study from the UK, 6.2 PA cases/100 000 population were identified (12). In small cohorts of asymptomatic non-functioning pituitary adenomas (NFPA) observed for a mean period of $\sim 5$ years, $7-9.5 \%$ developed PA $(13,14)$. However, no PA case was diagnosed in another NFPA cohort (with both micro- and macroadenomas) followed-up for a mean of 42 months, despite significant growth of the macroadenomas included (15). The prevalence seems to be lower in prolactinomas: in a large cohort treated in a single centre over 11 years, $<1 \%$ of clinical PAs were retrospectively identified (16).

The sex-ratio favours the male gender which is affected in $60-67 \%$ of cases $(2,7,17,18,19)$. The age range extends from childhood to later life, but most cases are diagnosed in the 5 th or 6 th decade $(10,18,20)$.

The most frequent type of preexisting adenoma appears to be NFPA (10), accounting for $45-82 \%$ of PA cases $(2,7,19,21,22,23)$. Prolactinomas and growth hormone (GH)-secreting pituitary adenomas follow, reported in $5.5-31 \%(2,7,19,22,23)$ and $7.2-25 \%$ of cases $(19,23)$, respectively. The relative dominance of NFPA cases may be an overestimation as in many cases, both the endocrinological assessment and the immunohistochemical examination were available after the acute damage of the pituitary gland and the tumour, raising the possibility of missing functioning pituitary adenomas. Notably, in more than half of the cases, no adenomatous cells can be identified in the sample sent for pathological examination $(7,18)$.

Rarely, PA has been reported to occur in nonadenomatous tissue: sellar tuberculoma (24), pituitary metastasis (25), abcess (26), lymphocytic hypophysitis (27), craniopharyngioma $(18,28)$, sellar hemangioblastoma (29) and Rathke's cleft cyst (30,31).

Sheehan's syndrome is a particular type of ischaemic necrosis of the anterior pituitary, occurring postpartum as a consequence of intrapartum haemorrhagic shock (32).

\section{Predisposing factors and pathogenesis}

The main reported predisposing factors are given in Table 1. Notably, two case-control studies did not find diabetes mellitus and arterial hypertension significantly more frequently in the PA group $(10,11)$.

All these factors presumably act through one of the following mechanisms: fluctuations of the blood pressure, hormonal stimulation of the gland, coagulation or vascular impairment (33). For many of these putative risk factors, causation has not been proved. In published series, possible precipitating factors have been found in

Table 1 Predisposing factors associated with PA.

\begin{tabular}{|c|c|}
\hline Predisposing factor & References \\
\hline \multicolumn{2}{|l|}{ Major surgery } \\
\hline Cardiac surgery & $(34,35,36,37,38,39)$ \\
\hline Vascular surgery & (40) \\
\hline Abdominal surgery & $(18)$ \\
\hline Knee or shoulder arthroplasty & $(41,42,43)$ \\
\hline \multicolumn{2}{|l|}{ Invasive procedures } \\
\hline Angiography & $(44,45)$ \\
\hline Spinal anaesthesia & $(46,47)$ \\
\hline \multicolumn{2}{|l|}{ Drugs } \\
\hline GNRH analogues & $(48,49,50,51)$ \\
\hline Somatostatin analogues & $(52)$ \\
\hline Dopamine agonists & $(53,54)$ \\
\hline $\begin{array}{l}\text { Dynamic endocrine tests using TRH, } \\
\text { GNRH, CRH, insulin or mixtures } \\
\text { of them }\end{array}$ & $(55,56,57,58,59,60)$ \\
\hline Arterial hypertension & $(2,19,61,62)$ \\
\hline $\begin{array}{l}\text { Anticoagulant or antithrombotic } \\
\text { medication }\end{array}$ & $(10,19,63,64,65)$ \\
\hline Diabetes mellitus & $(66)$ \\
\hline Contraceptive pills use & $(2)$ \\
\hline Closed head trauma & $(67,68)$ \\
\hline Radiotherapy & $(69)$ \\
\hline High altitude & $(70)$ \\
\hline \multicolumn{2}{|l|}{ Rare infectious diseases } \\
\hline e.g. Dengue haemorrhagic fever & (71) \\
\hline
\end{tabular}


$40 \%$ of cases (18); in others, the vast majority of cases occur spontaneously $(6,7,19)$.

The pathophysiology is not completely understood. Tumour necrosis due to either outgrowth of blood supply (1) or to compression of the pituitary vessels at the diaphragmatic notch (72) has been proposed as a pathogenetic mechanism which, however, is unlikely to explain all cases. Although PA is usually encountered in macroadenomas, mostly with significant suprasellar extension $(10,23)$, it has also been described in microadenomas, where alternative pathogenetic events probably occur $(73,74)$. Given that the risk of intratumour bleeding is 5.4 times higher for pituitary adenomas than for all other intracranian tumours (75), the possibility that pituitary adenomas have an intrinsic characteristic predisposing them to PA can not be excluded. Thus, an intratumoural vasculopathy rendering the vessels more susceptible to haemorrhage has been proposed as an option (76). Furthermore, a significant correlation between the intratumoural expression of VEGF $(13,77)$ and TNF $\alpha$ (78) and the presence of tumour haemorrhage has been found, suggesting a possible causal relationship, although other group did not confirm this finding $(79,80)$.

\section{Clinical presentation}

Frequently the PA episode is the first manifestation of a preexisting, previously unsuspected pituitary adenoma $(2,7,18)$. The clinical presentation occurs within a few hours or days (6) and results from the sudden expansion of the pituitary lesion due to the acute haemorrage or infarction. Semple et al. (81) suggested that the cases with ischaemic necrosis have a milder clinical course and a better outcome than those with haemorrhage or haemorrhagic necrosis.

The clinical manifestations are detailed in Table 2. Headache is the most frequent symptom. It occurs acutely, is very intense and frequently retroorbital (2), mimicking a wide range of acute neurological events. Nausea and vomiting are the second most common symptom further complicating the differential diagnosis (especially in patients with previously unknown pituitary tumours).

The distention of the optic chiasm or optic nerves by the bulging sellar mass or the sudden extension into the cavernous sinus is responsible for the frequent visual impairment - given in Table 2. Isolated acute cranial nerve (CN) palsies have been reported $(82,83,84,85)$ and they usually indicate a milder episode having good prognosis

Table 2 Clinical manifestations of pituitary apoplexy.

\begin{tabular}{|c|c|c|}
\hline Clinical manifestation & Frequency & References \\
\hline Headache & Over $90 \%$ & $(6,7,17,22,61,62,89)$ \\
\hline Nausea and vomiting & $43-80 \%$ & $(2,6,7,62,89)$ \\
\hline Visual impairment & $85 \%$ & (61) \\
\hline Rapid decrease in visual acuity (VA) & $39-56 \%$ & $(17,89)$ \\
\hline Unilateral or bilateral blindness & Up to $30 \%$ & $(90,91)$ \\
\hline New visual fields (VF) defects & $36-71 \%$ & $(2,7,22,62)$ \\
\hline Ocular paresis & $40-78 \%$ & $(6,7,17,22,89)$ \\
\hline Diplopia & $>50 \%$ & (62) \\
\hline $\begin{array}{l}\text { Possibly isolated acute cranial nerves } \\
\text { (CN) palsies }\end{array}$ & Occasionaly reported & $(82,83,84,85)$ \\
\hline Third (more frequent) & & $(6,62)$ \\
\hline $\begin{array}{l}\text { Fourth } \\
\text { Fifth CN }\end{array}$ & & $(2,92)$ \\
\hline Altered mental state & $13-42 \%$ & $(6,17,89)$ \\
\hline Coma & $6.2 \%$ & $(23)$ \\
\hline Hypopituitarism & $71-100 \%$ & $(10,18,61,86)$ \\
\hline Panhypopituitarism & $70 \%$ & (6) \\
\hline ACTH deficiency & $70-76 \%$ & \\
\hline Gonadotrophin deficiency & $76-79 \%$ & $(2,18,61)$ \\
\hline Central hypothyroidism & $50-57 \%$ & \\
\hline \multicolumn{3}{|l|}{ Hydroelectrolytic disturbances } \\
\hline Hyponatraemia & $12-44 \%$ & $(2,7,18,87)$ \\
\hline Diabetes insipidus & $0-8 \%$ & $(6,10,17,89)$ \\
\hline \multicolumn{3}{|l|}{ Other } \\
\hline Meningeal irritation & $\begin{array}{l}\text { Rare, secondary to the presence of } \\
\text { blood in the suprasellar space }\end{array}$ & (93) \\
\hline Unexplained hyperpyrexia & & $(2,6,89)$ \\
\hline Focal signs (cerebral infarction) & $\begin{array}{l}\text { Exceptional (compression of the } \\
\text { intracavernous carotid arteries) }\end{array}$ & (94) \\
\hline Sudden death & Exceptional & (95) \\
\hline
\end{tabular}


with conservative management (84). The third $\mathrm{CN}$ is most frequently affected due to its position, more close to the sella and possibly to its compression onto the interclinoid ligament, but multiple $\mathrm{CN}$ palsies and even bilateral lesions have been reported $(82,85)$.

Impaired consciousness is a sign of severity and it occurs more frequently in patients with associated predisposing factors (33).

Hypopituitarism is another major manifestation of $\mathrm{PA}$, probably secondary to the acute increase in the intrasellar pressure compressing the portal circulation, the pituitary stalk and the pituitary gland itself (86). Hyponatraemia can occur secondary to hypopituitarism or, rarely, to inappropriate $\mathrm{ADH}$ secretion $(7,87)$. Moderate hyperpolactinaemia (not consistent with a diagnosis of prolactinoma) is possible (2) and could indicate that some viable pituitary cells have resisted the acute destruction of the gland and that recovery of pituitary function after surgery is more likely (88).

The diagnosis is often difficult especially if there is no known previous history of pituitary pathology, and the differential diagnosis includes a number of conditions such as subarachnoid haemorrhage $(96,97)$, bacterial meningitis $(98,99)$, ophthalmoplegic migraine (100), suprasellar aneurysm (101), stroke (18), hypertensive encephalopathy and cavernous sinus thrombosis (102). Nevertheless, a high degree of suspicion should exist in any patient with severe sudden headache. This aims to avoid delay in proper management.

\section{Imaging}

Although not always pathognomonic, the imaging findings are of paramount importance in establishing the diagnosis on time. PA usually occurs in macroadenomas, more frequently those with cavernous sinus invasion (11) and the pituitary mass is usually evident on either CT or MRI. The intratumoural areas of haemorrhage and/or infarction are more frequently identified with $\operatorname{MRI}(2,18)$. On CT, recent haemorrhage presents as a hyperdense lesion with minimal contrast enhancement; later it becomes progressively less hyperdense, making the differential diagnosis from other intrapituitary lesions (e.g. cyst, abscesses) more difficult (103). However, in the first few hours from onset, the haemorrhage appears isointense or slightly hypointense on MRI images, so CT provides improved detection in this hyperacute stage (104).

The MRI findings depend on the time interval from the PA event. In the first few hours, haemorrhage can be missed on MRI and is better identified with CT. After this interval, acute haemorrhagic PA appears hyper/isointense on T1- and hypointense on T2-weighted images. This finding is not pathognomonic and should always be correlated with the clinical picture; a similar aspect can occur in Rathke's cysts containing mucoid material, in the absence of any acute event (31). Later (after about 7 days), the haemorrhagic area becomes hyperintense in both T1and T2-weighted images, while in the chronic phase (after about 2 weeks) a heterogeneous aspect is usually present. The centre is usually isointense on T1- and hyperintense on T2-weighted images, while the periphery has low signal (105) or a fluid level within the mass can occur (probably due to the sedimentation of blood products from an old intratumour haemorrhage) (104). Subacute or chronic haemorrhage is frequently identified even on nonenhanced MRI studies (which can reach the correct diagnosis in many instances) (105) and usually appears heterogeneous due to the presence of blood products in various stages (104) (Fig. 1).

Non-haemorrhagic changes (infarction alone) present as low intensity areas with no contrast-enhancement on MRI (20, 105), but can be easily missed on CT scans (104). The acute thickening of the sphenoid sinus mucosa, thought to result from venous compression in PA, was frequently noticed by some authors (106), but not by others (6).

In one study, the MRI images suggestive of haemorrhage or haemorrhagic infarction were confirmed in $87 \%$ (a)

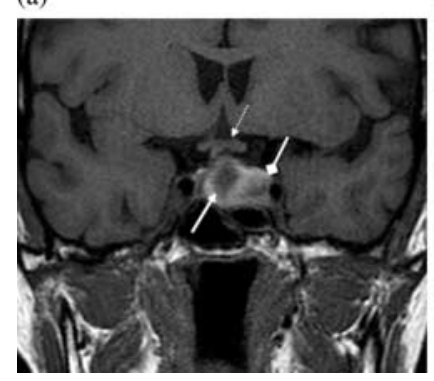

(b)

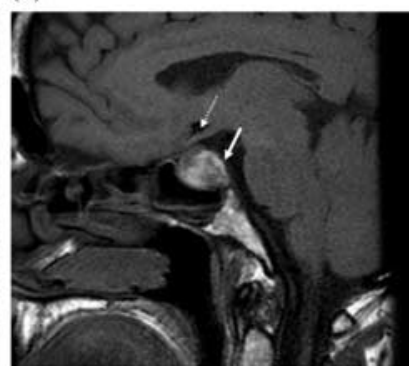

\section{Figure 1}

Pituitary MRI T1-weighted non-contrast-enhanced images suggestive of old PA - coronal (a) and sagittal section (b) - showing an enlarged pituitary fossa containing a heterogeneous mass lesion (thick, solid arrow), with areas showing older (hypointense) and more recent (hyperintense) regions of bleeding. Superiorly, the mass comes into contact with the optic chiasm (thin, dashed arrow), but the chiasm does not appear to be significantly compressed. There may be invasion of the left cavernous sinus (solid, diamond arrow) by the mass. 
of the cases at the histopathological examination. The concordance rate was similar (88\%) for the MRI findings suggestive of infarction alone (20). The ability of the MRI examination to accurately predict the histopathological findings in most cases can be important clinically as the outcome of the cases with haemorrhagic changes has been reported to be worse than that of the cases with infarction alone $(20,81)$.

\section{Management}

All patients suspected of PA should have urgent testing for electrolytes, full blood count, renal and liver function, coagulation, pituitary function (with serum cortisol and thyroid hormones being of particular importance), as well as formal neuroophthalmological assessment and radiological assessment (preferably MRI, whenever possible) (107).

Immediate administration of high-dose glucocorticoids should be initiated before the tests results are available, especially in haemodynamically unstable cases or with severe neurological or neuroopthalmological signs, as it covers not only the increased risk of hypoadrenalism but also has significant antiinflammatory and antioedematous effects $(107,108)$. In these cases, a random cortisol should be sampled on presentation and glucocorticoids initiated immediately. In milder cases, if $0900 \mathrm{~h}$ serum cortisol is below $550 \mathrm{nmol} / \mathrm{l}$ (or other cut-off depending on the local assay) glucocorticoids administration should be considered. Hydrocortisone was preferentially used in the reported series; recommended dosage regimes are based on expert opinions (107), but no objective data are available at present. The role of dexamethasone in high doses (up to $16 \mathrm{mg} /$ day) instead of stress dose hydrocortisone has not been formally evaluated in acute PA, but its use has been reported in a number of cases $(19,91)$, especially where an antioedematous effect is sought. There are no good comparative data, and a randomised controlled trial comparing dexamethasone with hydrocortisone is also required to determine if either results in a superior outcome.

In the past, PA has been considered an emergency situation in which immediate neurosurgical intervention is needed $(8,109)$. However, some patients treated conservatively recover without sequelae (95), while recovery of neuroophthalmic function can also occur after delayed decompression (at an average of 19 days after presentation) (93). Therefore, the debate around the optimal management strategy still persists. Due to its rare occurence, large series of patients with PA are rare and evidence-based criteria guiding the management of these patients are difficult to obtain, and this probably necessitates a multicentre trial.

\section{Surgery}

Indications $\downarrow$ Neuroophthalmic complications (visual fields (VF) and visual acuity (VA) impairment) are an indication for decompressive surgery in most series $(2,19,108,110)$. There are no established criteria to define the neuroophthalmological deficit requiring neurosurgical intervention, and recently a scoring tool has been designed, the pituitary apoplexy score (PAS) (111). The retrospective analysis of two large case series revealed significant differences between the PAS in cases treated with emergency surgical intervention, delayed surgery or conservative management $(19,111)$. The data suggested that a PAS over four might be an argument for emergency surgery, but prospective studies are needed for further validation. Another clinical grading system with potential implications for PA management was recently developed (112).

Impaired consciousness is also a frequent indication for surgery $(108,110)$. Ocassionally, complete recovery of the mental state with conservative management has been reported, but generally the course is variable and unpredictable $(23,95)$ making urgent decompression the preferred option.

Surgery is also offered in the presence of deteriorating visual or neurological signs or of further enlargement of the sellar mass on serial imaging, usually as a delayed elective intervention $(19,108)$. Isolated ophthalmoplegia is not an indication for surgery (107), as it almost always recovers with conservative management $(18,19)$.

If severe comorbidities contraindicate early surgery, a conservative approach is initially taken $(10,113)$ and a delayed intervention (if possible) may offer some prospect of improvement (e.g. recovering useful vision in previously blind eyes) (90). Transsphenoidal surgery is preferred, due to its low morbidity and mortality rates (108).

Outcome - Visual $\downarrow$ Surgery leads to the resolution/ improvement of visual manifestations in the majority of cases. Thus VF defects improve after surgery in 57-95\% of the cases $(2,6,7,10,18,22,62,112)$, while complete or significant improvement in VA occurs in $86-93 \%(2,18$, $22,114)$. Due to the low tolerance of the optic nerve system to ischaemia, both severe impairment and long interval until treatment are important predictors of a poor recovery (113). It has been suggested that VA and 
VF recover significantly better in cases operated within $<7-8$ days from presentation $(2,6,22,90,113)$. VF deficits improved in $75 \%$ of cases operated in the first 8 days compared with $23 \%$ of those operated later (2). Agrawal \& Mahapatra (90) found that half of the completely blind eyes showed recovery when operated within a week from admission. The improvement in visual function occurs immediately after surgery and continues for variable intervals $(90,113)$. A similar trend but without statistical significance has been observed by other authors $(18,19$, $62,114)$. However, in some of these reports conservative management was initially offered and surgery (early or delayed) was only indicated if aggravation occured or no improvement was noticed within a few days.

Ocular paresis improves in $63-100 \%$ of operated PA cases, progressively during the first 3 months postoperatively, with no further benefit afterwards $(6,7,10,18,19$, $22,62,114)$. As opposed to the visual function, the ophthalmoplegia usually recovers even with delayed surgery (115). The timing of surgery does not influence the outcome (2), but the recovery time is shorter if early surgery is performed (114).

Endocrinological $\triangleright$ Some degree of hypopituitarism remains in $61-86 \%$ of operated PA cases $(7,10,113)$. In one series, the patients without severe underlying diseases had a lower rate of postoperative hypopituitarism (33\%) than those with severe comorbidities (86\%), but the authors offer no possible explanation for this finding (113). Postoperative hypogonadism remains in 55-79\%, hypothyroidism in $45-60 \%$, and ACTH deficiency in $40-87 \%$ of cases $(2,7,10,62)$. GH deficiency, although rarely assessed, appears to be the most common (84\%) (116). Despite its high prevalence postoperatively, pituitary dysfunction is consistently reported to improve after surgery, compared with the presurgical status $(2,6,18,19)$. In one study, the number of patients requiring hormone replacement decreased steadily from 1 month to 2 years postoperatively, suggesting the possibility of slow recovery of the pituitary function (117).

Significant improvement of the pituitary dysfunction has been reported in one study (86), in which the authors concluded that early surgery allows reversal of the hypopituitarism attributed to the acute compression of the portal vessels by the enlarging pituitary mass. This favourable outcome was not replicated by others (10). Notably, based on objective measurements of intrasellar pressure, endocrine recovery is possible only in cases with moderate pressure elevations, not definitively compromising the surrounding normal pituitary (88).
In a recently published retrospective surgical series, a grading system based on clinical findings has been proposed; lower grades (1-3) were more frequently associated with complete recovery of the hypopituitarism than higher grades (4-5) (112).

Transient DI is diagnosed in $16-35 \%$ of cases after surgery $(2,6,7)$, but permanent DI occurs infrequently $(2-11 \%)(2,7,10,22)$.

Tumour removal $\triangleright$ After surgery, complete removal of the pituitary mass is reported in $48-66 \%$ of the cases $(7,113,117,118)$ and subtotal resection in $23-52 \%$ of cases $(113,118)$.

Mortality Postoperative mortality is generally low, ranging from $0 \%(2,19)$ to $5-15.3 \%$ (assessed at 4 days-6 months after the neurosurgical intervention; in these series, infectious aetiologies were also included without clear causal relationship with the intervention) $(6,7,113)$.

The standardised mortality rate calculated in 41 operated PA cases followed-up for a median period of 13.7 years did not differ from that of operated NFPA without PA and of the general population (89).

\section{Conservative management}

Indications $\vee$ The conservative management of the PA patient includes careful initial assessment and high-dose glucocorticoids as previously described, replacement of pituitary deficits, if present, frequent monitoring of the fluids and electrolytes balance. Repeated formal neuroophthalmological testing is required to monitor the evolution of visual function. Continuous careful monitoring is mandatory because, despite an initial less worrisome presentation, the clinical course can suddenly worsen, with even lethal consequences $(23,119)$.

The indications for conservative management vary and in some series, most patients are initially managed conservatively and only cases with progressive impairment in visual function or level of consciousness proceed to neurosurgical decompression (62). In others, conservative treatment is offered only in the elderly, frail or oligosymptomatic patients (6).

Outcome $\checkmark$ Visual $\triangleright$ Complete resolution or marked improvement of VF and CNs palsies has been reported in $80-100 \%$ and $100 \%$ of conservatively managed cases respectively $(18,19,62)$. Although this outcome appears better than the one after surgical intervention, there is an important selection bias. Thus, these patients have 
significantly less VF and VA impairment at presentation $(18,19)$ and those showing progressive manifestations whilst on conservative care proceeded to surgery (18.2\% of cases in one series) (19). Despite this, the frequent evolution towards visual recovery in these cases suggests that patients with mild, stable clinical presentation or with improvement within the first few days could safely be managed conservatively (18).

Endocrinological $\bullet$ Hypopituitarism is frequent following conservative management with one series reporting that $90 \%$ of the patients remained on long-term replacement treatment (19). In another study, $72 \%$ of the cases remained ACTH deficient, $87 \%$ had persistent hypothyroidism and $83 \%$ central hypogonadism, figures slightly higher than the prevalence of the corresponding deficiencies at diagnosis (62). No recovery of the endocrine dysfunction was described in the conservatively managed cases in one series (18). Notably, patients showing resolution of the pituitary mass after the apoplexy had a significantly higher rate of pituitary deficiencies (91).

Tumour outcome $>$ Disappearance of the pituitary mass after a PA episode treated conservatively has been described and marked shrinkage occurs in over half of the cases, significantly associated with the presence of a single intratumoural hypodense area on CT (91).

Cases of spontaneous biochemical remission after PA have been reported for GH-secreting (120, 121, 122), ACTH-secreting $(18,123,124)$ and prolactin-secreting (122) tumours. However, in a large case series, $90 \%$ of the functioning tumours remained active following PA, the majority of which required surgery (19).

Mortality Although one series reported no mortality (18), in another one including six patients offered conservative management, three had worsening of the clinical manifestatons leading to death in 4-14 days from admission (23). This underlines the need for very careful selection and monitoring of PA cases managed conservatively.

\section{Surgery vs conservative management}

In most series, a comparison between the two approaches is not possible due to the selection bias as patients most severely affected were directed towards surgery. Bearing this in mind, it seems that the endocrine $(18,19,61,62$, $91)$ and visual $(18,19,61,62,101)$ outcomes are similar in operated and conservatively managed cases. However, a randomised trial is needed for obtaining robust evidence.
At the present time, available literature indicates that cases with a mild clinical picture, without severe, progressing neuroophthalmic signs can safely be managed conservatively.

\section{Recurrence}

In patients with a functioning adenoma, recurrence after the initial biochemical cure is possible $(18,123,125,126)$, necessitating long-term follow-up. In a series of NFPA presenting with apoplexy, treated surgically and followedup for a mean period of 6.6 years, the regrowth rate was $11 \%$. All recurrences were in the group with subtotal initial resection not followed by adjuvant radiotherapy (118). In an earlier series, $20 \%$ (2/10 cases) of the operated patients had a recurrence of their adenoma within 10 years (23). Although these rates are less than those observed in operated NFPA not undergoing PA $(34.8 \%$ at 7.3 years (127)), they are higher than expected.

Data on the risk of regrowth of pituitary adenomas presenting with apoplexy and managed conservatively are limited and rely on series including both treatment options $(2,62,91)$.

However, it seems that recurrences are more frequent in the conservative group (18), although the small number of cases and treatment-decision bias make a reliable comparison impossible. Recurrence of bleeding in the tumour remnant has been described, even years after the initial surgery $(2,128)$.

\section{Follow-up}

Given the risk of tumour regrowth, long-term follow-up of apoplectic pituitary tumours is recommended. This does not differ from that of patients with non-apoplectic pituitary adenomas and includes early post-operative assessement of the pituitary reserve (with appropriate treatment) and vision followed by annual clinical review. Pituitary imaging is recommended 3-6 months postoperatively, then annualy in the first 5 years and biannually thereafter. In case of tumour recurrence, management is individualised and includes monitoring, repeat surgery, radiotherapy or combination of surgery and pituitary irradiation $(129,130)$.

\section{Management: summary}

Immediate administration of stress doses of glucocorticoids should be offered in all cases with clinical suspicion or confirmed hypoadrenalism (107). Milder cases (with 


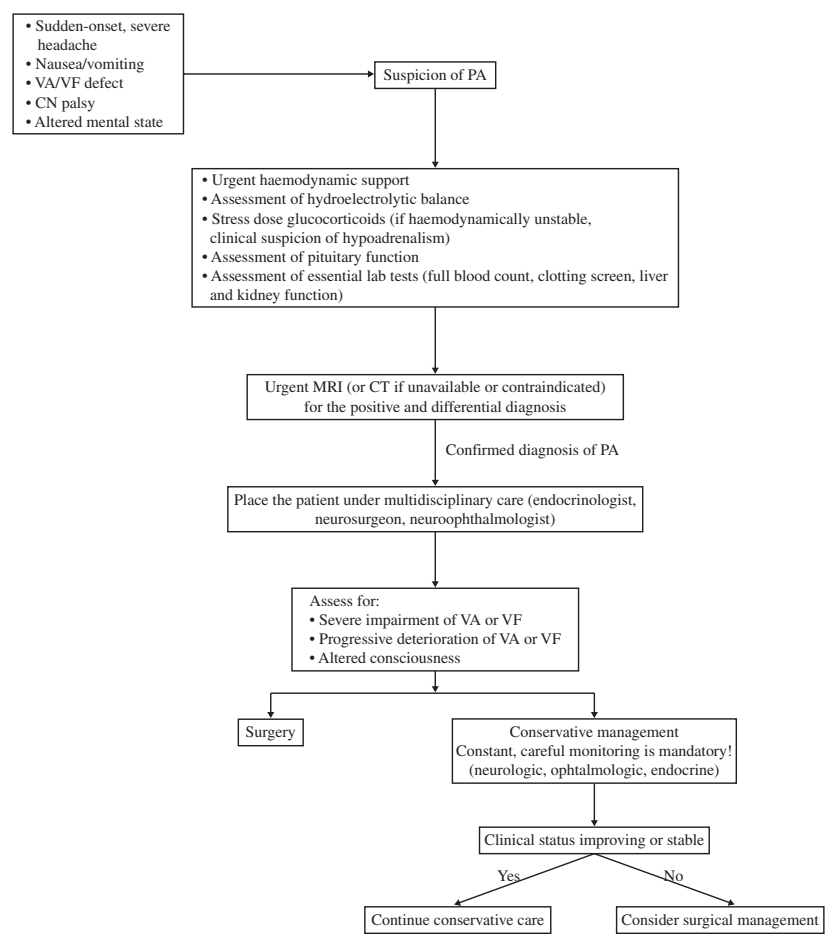

Figure 2

Algorithm for the management of pituitary tumour apoplexy.

preserved consciousness, minor or spontaneously improving visual signs, isolated ophthalmoplegia) can be safely managed conservatively after a thorough initial evaluation by a multidisciplinary team (endocrinologist, neurosurgeon, neuroophthalmologist) and careful, frequent reassessment $(18,91,131)$. Constant monitoring is essential because the course is unpredictable and can even lead to death when evolution is unfavourable (23).

For patients with altered consciousness or VF/VA defects, early surgical intervention (preferably within 1 week) is indicated $(91,108,110,113)$ and is associated with improved visual (2) and possibly endocrinological $(86,113)$ outcome. Delayed surgery (if early intervention is not possible) is still beneficial, especially in terms of vision (2).

When appropriate parameters to assess indications for surgical intervention are utilised, the conservative approach does not lead to worse endocrine, visual or neurological outcome compared with patients undergoing routine surgery $(19,61,62,91,108)$. The algorithm for the management of PA is illustrated in Fig. 2.

Recurrences can occur both following surgical and conservative approach and the management strategy includes monitoring, repeat surgery and radiotherapy.

\section{Conclusions}

Pituitary tumour apoplexy is a potentially life-threatening clinical syndrome caused by ischaemic infarction or haemorrhage into a pituitary tumour. The diagnosis should be suspected in all cases with sudden-onset severe headache, with or without neuroophthalmic manifestations. Ideally, as soon as the diagnosis is established, the patient should be under the care of a multidisciplinary team including endocrinologist, neurosurgeon and neuroophthalmologist. In cases with severe, progressing visual or neurological manifestations, surgical decompression is indicated. Patients with mild, stable clinical picture can be managed conservatively. With the proposed multidisciplinary approach, the visual and neurological outcomes are favourable in most cases. The endocrinological prognosis is less favourable with many patients requiring replacement therapy. In view of the risk of tumour regrowth, long-term follow-up is necessary.

Prospective randomised trials are necessary to put the management of pituitary tumour apoplexy on a sounder scientific footing.

Declaration of interest

The authors declare that there is no conflict of interest that could be perceived as prejudicing the impartiality of the review.

\section{Funding}

This research did not receive any specific grant from any funding agency in the public, commercial or not-for-profit sector.

\section{References}

1 Brougham M, Heusner AP \& Adams RD. Acute degenerative changes in adenomas of the pituitary body - with special reference to pituitary apoplexy. Journal of Neurosurgery 19507 421-439. (doi:10.3171/jns. 1950.7.5.0421)

2 Randeva HS, Schoebel J, Byrne J, Esiri M, Adams CB \& Wass JA. Classical pituitary apoplexy: clinical features, management and outcome. Clinical Endocrinology 199951 181-188. (doi:10.1046/j.13652265.1999.00754.x)

3 Findling JW, Tyrrell JB, Aron DC, Fitzgerald PA, Wilson CB \& Forsham PH. Silent pituitary apoplexy: subclinical infarction of an adrenocorticotropin-producing pituitary adenoma. Journal of Clinical Endocrinology and Metabolism 1981 52 95-97. (doi:10.1210/ jcem-52-1-95)

4 Peter SA. Subclinical pituitary apoplexy. New York State Journal of Medicine 198686 656-657.

5 Wakai S, Fukushima T, Teramoto A \& Sano K. Pituitary apoplexy: its incidence and clinical significance. Journal of Neurosurgery 198155 187-193. (doi:10.3171/jns.1981.55.2.0187)

6 Dubuisson AS, Beckers A \& Stevenaert A. Classical pituitary tumour apoplexy: clinical features, management and outcomes in a series of 
24 patients. Clinical Neurology and Neurosurgery 2007109 63-70. (doi:10.1016/j.clineuro.2006.01.006)

7 Lubina A, Olchovsky D, Berezin M, Ram Z, Hadani M \& Shimon I. Management of pituitary apoplexy: clinical experience with 40 patients. Acta Neurochirurgica 2005147 151-157. (doi:10.1007/s00701004-0413-2)

8 Bonicki W, Kasperlik-Zaluska A, Koszewski W, Zgliczynski W \& Wislawski J. Pituitary apoplexy: endocrine, surgical and oncological emergency. Incidence, clinical course and treatment with reference to 799 cases of pituitary adenomas. Acta Neurochirurgica $1993 \mathbf{1 2 0}$ 118-122. (doi:10.1007/BF02112028)

9 Mohr G \& Hardy J. Hemorrhage, necrosis, and apoplexy in pituitary adenomas. Surgical Neurology 198218 181-189. (doi:10.1016/00903019(82)90388-3)

10 Moller-Goede DL, Brandle M, Landau K, Bernays RL \& Schmid C. Pituitary apoplexy: re-evaluation of risk factors for bleeding into pituitary adenomas and impact on outcome. European Journal of Endocrinology 2011164 37-43. (doi:10.1530/EJE-10-0651)

11 Cinar N, Tekinel Y, Dagdelen S, Oruckaptan H, Soylemezoglu F \& Erbas T. Cavernous sinus invasion might be a risk factor for apoplexy. Pituitary 201316 483-489. (doi:10.1007/s11102-012-0444-2)

12 Fernandez A, Karavitaki N \& Wass JA. Prevalence of pituitary adenomas: a community-based, cross-sectional study in Banbury (Oxfordshire, UK). Clinical Endocrinology 201072 377-382. (doi:10.1111/j.1365-2265.2009.03667.x)

13 Arita K, Tominaga A, Sugiyama K, Eguchi K, Iida K, Sumida M, Migita K \& Kurisu K. Natural course of incidentally found nonfunctioning pituitary adenoma, with special reference to pituitary apoplexy during follow-up examination. Journal of Neurosurgery 2006104 884-891. (doi:10.3171/jns.2006.104.6.884)

14 Nishizawa S, Ohta S, Yokoyama T \& Uemura K. Therapeutic strategy for incidentally found pituitary tumors ("pituitary incidentalomas"). Neurosurgery 199843 1344-1348.

15 Karavitaki N, Collison K, Halliday J, Byrne JV, Price P, Cudlip S \& Wass JA. What is the natural history of nonoperated nonfunctioning pituitary adenomas? Clinical Endocrinology 2007 67 938-943. (doi:10.1111/j.1365-2265.2007.02990.x)

16 Sarwar KN, Huda MS, Van de Velde V, Hopkins L, Luck S, Preston R, McGowan BM, Carroll PV \& Powrie JK. The prevalence and natural history of pituitary hemorrhage in prolactinoma. Journal of Clinical Endocrinology and Metabolism 201398 2362-2367. (doi:10.1210/jc. 2013-1249)

17 Semple PL, Webb MK, De Villiers JC \& Laws ER Jr. Pituitary apoplexy. Neurosurgery 200556 65-72.

18 Sibal L, Ball SG, Connolly V, James RA, Kane P, Kelly WF, Kendall-Taylor P, Mathias D, Perros P, Quinton R et al. Pituitary apoplexy: a review of clinical presentation, management and outcome in 45 cases. Pituitary 20047 157-163. (doi:10.1007/s11102005-1050-3)

19 Bujawansa S, Thondam SK, Steele C, Cuthbertson DJ, Gilkes CE, Noonan C, Bleaney CW, Macfarlane IA, Javadpour M \& Daousi C. Presentation, management and outcomes in acute pituitary apoplexy: a large single-centre experience from the United Kingdom. Clinical Endocrinology 201480 419-424. (doi:10.1111/cen.12307)

20 Semple PL, Jane JA, Lopes MB \& Laws ER. Pituitary apoplexy: correlation between magnetic resonance imaging and histopathological results. Journal of Neurosurgery 2008 108 909-915. (doi:10.3171/ JNS/2008/108/5/0909)

21 Nawar RN, Abdelmannan D, Selman WR \& Arafah BM. Pituitary tumor apoplexy: a review. Journal of Intensive Care Medicine 200823 75-90. (doi:10.1177/0885066607312992)

22 Bills DC, Meyer FB, Laws ER Jr, Davis DH, Ebersold MJ, Scheithauer BW, Ilstrup DM \& Abboud CF. A retrospective analysis of pituitary apoplexy. Neurosurgery 199333 602-608. (doi:10.1227/ 00006123-199310000-00007)
23 da Motta LA, de Mello PA, de Lacerda CM, Neto AP, da Motta LD \& Filho MF. Pituitary apoplexy. Clinical course, endocrine evaluations and treatment analysis. Journal of Neurosurgical Sciences 199943 25-36.

24 Verma R, Patil TB \& Lalla R. Pituitary apoplexy syndrome as the manifestation of intracranial tuberculoma. BMJ Case Reports 2014. (doi:10.1136/bcr-2013-201272)

25 Kruljac I, Cerina V, Pecina HI, Pazanin L, Matic T, Bozikov V \& Vrkljan M. Pituitary metastasis presenting as ischemic pituitary apoplexy following heparin-induced thrombocytopenia. Endocrine Pathology 201223 264-267. (doi:10.1007/s12022-012-9224-9)

26 Kingdon CC, Sidhu PS \& Cohen J. Pituitary apoplexy secondary to an underlying abscess. Journal of Infection 199633 53-55. (doi:10.1016/ S0163-4453(96)92814-5)

27 Dan NG, Feiner RI, Houang MT \& Turner JJ. Pituitary apoplexy in association with lymphocytic hypophysitis. Journal of Clinical Neuroscience 20029 577-580. (doi:10.1054/jocn.2001.0975)

28 Lloyd MH \& Belchetz PE. The clinical features and management of pituitary apoplexy. Postgraduate Medical Journal 197753 82-85. (doi:10.1136/pgmj.53.616.82)

29 Schar RT, Vajtai I, Sahli R \& Seiler RW. Manifestation of a sellar hemangioblastoma due to pituitary apoplexy: a case report. Journal of Medical Case Reports 20115 496. (doi:10.1186/1752-1947-5-496)

30 Chaiban JT, Abdelmannan D, Cohen M, Selman WR \& Arafah BM. Rathke cleft cyst apoplexy: a newly characterized distinct clinical entity. Journal of Neurosurgery 2011114 318-324. (doi:10.3171/2010.5. JNS091905)

31 Trifanescu R, Ansorge O, Wass JA, Grossman AB \& Karavitaki N. Rathke's cleft cysts. Clinical Endocrinology 201276 151-160. (doi:10.1111/j.1365-2265.2011.04235.x)

32 Sheehan HL. Postpartum necrosis of the anterior pituitary. Journal of Pathology and Bacteriology 193745 189-214. (doi:10.1002/path. 1700450118)

33 Biousse V, Newman NJ \& Oyesiku NM. Precipitating factors in pituitary apoplexy. Journal of Neurology, Neurosurgery, and Psychiatry 200171 542-545. (doi:10.1136/jnnp.71.4.542)

34 Absalom M, Rogers KH, Moulton RJ \& Mazer CD. Pituitary apoplexy after coronary artery surgery. Anesthesia and Analgesia $1993 \mathbf{7 6}$ 648-649. (doi:10.1213/00000539-199303000-00036)

35 Cooper DM, Bazaral MG, Furlan AJ, Sevilla E, Ghattas MA, Sheeler LR, Little JR, Hahn JF, Sheldon WC \& Loop FD. Pituitary apoplexy: a complication of cardiac surgery. Annals of Thoracic Surgery $1986 \mathbf{4 1}$ 547-550. (doi:10.1016/S0003-4975(10)63039-1)

36 Mattke AF, Vender JR \& Anstadt MR. Pituitary apoplexy presenting as Addisonian crisis after coronary artery bypass grafting. Texas Heart Institute Journal 200229 193-199.

37 Shapiro LM. Pituitary apoplexy following coronary artery bypass surgery. Journal of Surgical Oncology 199044 66-68. (doi:10.1002/jso.2930440115)

38 Tansel T, Ugurlucan M \& Onursal E. Pituitary apoplexy following coronary artery bypass grafting: report of a case. Acta Chirurgica Belgica $2010110484-486$.

39 Meek EN, Butterworth J, Kon ND, Zvara DA, Ash GE Jr \& Martin TJ. Pituitary apoplexy following mitral valve repair. Anesthesiology 1998 89 1580-1582. (doi:10.1097/00000542-199812000-00042)

40 Liberale G, Bruninx G, Vanderkelen B, Dubois E, Vandueren E \& Verhelst G. Pituitary apoplexy after aortic abdominal aneurysm surgery: a case report. Acta Chirurgica Belgica 2006106 77-80.

41 Koga T, Miyao M, Sato M, Hirota K, Kakuyama M, Tanabe H \& Fukuda K. Pituitary apoplexy during general anesthesia in beach chair position for shoulder joint arthroplasty. Journal of Anesthesia 201024 476-478. (doi:10.1007/s00540-010-0929-y)

42 Madhusudhan S, Madhusudhan TR, Haslett RS \& Sinha A. Pituitary apoplexy following shoulder arthroplasty: a case report. Journal of Medical Case Reports 20115 284. (doi:10.1186/1752-1947-5-284)

43 Khandelwal M, Chhabra A \& Krishnan S. Pituitary apoplexy following bilateral total knee arthroplasty. Journal of Postgraduate Medicine 2005 51 155-156. 
44 Louwerens M, de Herder WW, Postema PT, Tanghe HL \& Lamberts SW. Pituitary insufficiency and regression of acromegaly caused by pituitary apoplexy following cerebral angiography. European Journal of Endocrinology 1996134 737-740. (doi:10.1530/eje.0. 1340737)

45 Reichenthal E, Manor RS \& Shalit MN. Pituitary apoplexy during carotid angiography. Acta Neurochirurgica 198054 251-255. (doi:10.1007/BF01407092)

46 Lennon M, Seigne P \& Cunningham AJ. Pituitary apoplexy after spinal anaesthesia. British Journal of Anaesthesia $1998 \mathbf{8 1} 616-618$. (doi:10.1093/bja/81.4.616)

47 Mathur D, Lim LF, Mathur M \& Sng BL. Pituitary apoplexy with reversible cerebral vasoconstrictive syndrome after spinal anaesthesia for emergency caesarean section: an uncommon cause for postpartum headache. Anaesthesia and Intensive Care 2014 42 99-105.

48 Ando S, Hoshino T \& Mihara S. Pituitary apoplexy after goserelin. Lancet 1995345 458. (doi:10.1016/S0140-6736(95)90443-3)

49 Blaut K, Wisniewski P, Syrenicz A \& Sworczak K. Apoplexy of clinically silent pituitary adenoma during prostate cancer treatment with LHRH analog. Neuro Endocrinology Letters 200627 569-572.

50 Huang TY, Lin JP, Lieu AS, Chen YT, Chen HS, Jang MY, Shen JT, Wu WJ, Huang SP \& Juan YS. Pituitary apoplexy induced by gonadotropin-releasing hormone agonists for treating prostate cancer-report of first Asian case. World Journal of Surgical Oncology 2013 11 254. (doi:10.1186/1477-7819-11-254)

51 Morsi A, Jamal S \& Silverberg JD. Pituitary apoplexy after leuprolide administration for carcinoma of the prostate. Clinical Endocrinology 199644 121-124. (doi:10.1046/j.1365-2265.1996.644465.x)

52 Bakiri F, Herrera J, Riestra M, Perrichot O, Pertierra J, Bruno OD, Brue T \& Castinetti F. Pituitary apoplexy after somatostatin analogue administration: coincidental or causative? Clinical Endocrinology 2014 81 471-473. (doi:10.1111/cen.12339)

53 Carija R \& Vucina D. Frequency of pituitary tumor apoplexy during treatment of prolactinomas with dopamine agonists: a systematic review. CNS \& Neurological Disorders Drug Targets 201211 1012-1014. (doi:10.2174/1871527311211080011)

54 Chng E \& Dalan R. Pituitary apoplexy associated with cabergoline therapy. Journal of Clinical Neuroscience 201320 1637-1643. (doi:10. 1016/j.jocn.2013.02.027)

55 Dokmetas HS, Selcuklu A, Colak R, Unluhizarci K, Bayram F \& Kelestimur F. Pituitary apoplexy probably due to TRH and GnRH stimulation tests in a patient with acromegaly. Journal of Endocrinological Investigation 199922 698-700. (doi:10.1007/BF03343632)

56 Kilicli F, Dokmetas HS \& Gurelik M. Development of pituitary apoplexy during TRH/GnRH test in a patient with pituitary macroadenoma. Singapore Medical Journal 201051 e179-e181.

57 Lee DH, Chung MY, Chung DJ, Kim JM, Lee TH, Nam JH \& Park CS. Apoplexy of pituitary macroadenoma after combined test of anterior pituitary function. Endocrine Journal 200047 329-333. (doi:10.1507/ endocrj.47.329)

58 Haakens K, Frey HM \& Haug E. Pituitary apoplexy after injection of pituitary-hormone releasing hormones. Tidsskrift for Den Norske Laegeforening 1994114 1612-1613.

59 Matsuura I, Saeki N, Kubota M, Murai H \& Yamaura A. Infarction followed by hemorrhage in pituitary adenoma due to endocrine stimulation test. Endocrine Journal 200148 493-498. (doi:10.1507/ endocrj.48.493)

60 Yoshino A, Katayama Y, Watanabe T, Ogino A, Ohta T, Komine C, Yokoyama T, Fukushima T \& Hirota H. Apoplexy accompanying pituitary adenoma as a complication of preoperative anterior pituitary function tests. Acta Neurochirurgica 2007149 557-565. (doi:10.1007/ s00701-007-1155-8)

61 Leyer C, Castinetti F, Morange I, Gueydan M, Oliver C, ConteDevolx B, Dufour H \& Brue T. A conservative management is preferable in milder forms of pituitary tumor apoplexy. Journal of Endocrinological Investigation 201134 502-509. (doi:10.3275/7241)
62 Ayuk J, McGregor EJ, Mitchell RD \& Gittoes NJ. Acute management of pituitary apoplexy - surgery or conservative management? Clinical Endocrinology 200461 747-752. (doi:10.1111/j.1365-2265.2004. 02162.x)

63 Nagarajan DV, Bird D \& Papouchado M. Pituitary apoplexy following anticoagulation for acute coronary syndrome. Heart $2003 \mathbf{8 9} 10$. (doi:10.1136/heart.89.1.10)

64 Willamowicz AS \& Houlden RL. Pituitary apoplexy after anticoagulation for unstable angina. Endocrine Practice 19995 273-276. (doi:10.4158/EP.5.5.273)

65 Nourizadeh AR \& Pitts FW. Hemorrhage into pituitary adenoma during anticoagulant therapy. Journal of the American Medical Association 1965193 623-625. (doi:10.1001/jama.1965. 03090070073033)

66 Brennan CF, Malone RG \& Weaver JA. Pituitary necrosis in diabetes mellitus. Lancet 1956271 12-16. (doi:10.1016/S01406736(56)91387-3)

67 Holness RO, Ogundimu FA \& Langille RA. Pituitary apoplexy following closed head trauma. Case report. Journal of Neurosurgery 1983 59 677-679. (doi:10.3171/jns.1983.59.4.0677)

68 Uchiyama H, Nishizawa S, Satoh A, Yokoyama T \& Uemura K. Post-traumatic pituitary apoplexy - two case reports. Neurologia Medico-Chirurgica 199939 36-39. (doi:10.2176/nmc.39.36)

69 Weisberg LA. Pituitary apoplexy. Association of degenerative change in pituitary ademona with radiotherapy and detection by cerebral computed tomography. American Journal of Medicine 197763 109-115. (doi:10.1016/0002-9343(77)90122-X)

70 Brar KS \& Garg MK. High altitude-induced pituitary apoplexy. Singapore Medical Journal 201253 e117-e119.

71 Kumar V, Kataria R \& Mehta VS. Dengue hemorrhagic fever: a rare cause of pituitary tumor hemorrhage and reversible vision loss. Indian Journal of Ophthalmology 201159 311-312. (doi:10.4103/0301-4738. 82002)

72 Rovit RL \& Fein JM. Pituitary apoplexy: a review and reappraisal. Journal of Neurosurgery 197237 280-288. (doi:10.3171/jns.1972.37.3. 0280)

73 Jeffcoate WJ \& Birch CR. Apoplexy in small pituitary tumours. Journal of Neurology, Neurosurgery, and Psychiatry 198649 1077-1078. (doi:10.1136/jnnp.49.9.1077)

74 Randall BR \& Couldwell WT. Apoplexy in pituitary microadenomas. Acta Neurochirurgica 2010152 1737-1740. (doi:10.1007/s00701-0100706-6)

75 Wakai S, Yamakawa K, Manaka S \& Takakura K. Spontaneous intracranial hemorrhage caused by brain tumor: its incidence and clinical significance. Neurosurgery 198210 437-444. (doi:10.1227/ 00006123-198204000-00004)

76 Cardoso ER \& Peterson EW. Pituitary apoplexy: a review. Neurosurgery 198414 363-373. (doi:10.1227/00006123-198403000-00021)

77 Jin KY, Hyun KC, Hwan CJ \& Min KJ. Relationship between expression of vascular endothelial growth factor and intratumoral hemorrhage in human pituitary adenomas. Tumori 201197 639-646.

78 Xiao Z, Liu Q, Mao F, Wu J \& Lei T. TNF $\alpha$-induced VEGF and MMP-9 expression promotes hemorrhagic transformation in pituitary adenomas. International Journal of Molecular Sciences $2011 \mathbf{1 2}$ 4165-4179. (doi:10.3390/ijms12064165)

79 Fukui S, Otani N, Nawashiro H, Yano A, Nomura N, Tokumaru AM, Miyazawa T, Ohnuki A, Tsuzuki N, Katoh H et al. The association of the expression of vascular endothelial growth factor with the cystic component and haemorrhage in pituitary adenoma. Journal of Clinical Neuroscience 200310 320-324. (doi:10.1016/S0967-5868(03)00013-4)

80 Fukui S, Nawashiro H, Otani N, Ooigawa H, Yano A, Nomura N, Tokumaru AM, Miyazawa T, Ohnuki A, Tsuzuki N et al. Vascular endothelial growth factor expression in pituitary adenomas. Acta Neurochirurgica. Supplement 200386 519-521.

81 Semple PL, De Villiers JC, Bowen RM, Lopes MB \& Laws ER Jr. Pituitary apoplexy: do histological features influence the clinical presentation 
and outcome? Journal of Neurosurgery 2006104 931-937. (doi:10.3171/ jns.2006.104.6.931)

82 Delgado-Alvarado M, Riancho J, Riancho-Zarrabeitia L, Sedano MJ, Polo JM \& Berciano J. Unilateral total ophthalmoplegia without visual loss as the presenting form of a pituitary apoplexy. Revista Clínica Española 2013213 e67-e70.

83 Diyora B, Nayak N, Kukreja S \& Kamble H. Sudden onset isolated complete third nerve palsy due to pituitary apoplexy. Oman Journal of Ophthalmology 20114 32-34. (doi:10.4103/0974-620X.77661)

84 Lee CC, Cho AS \& Carter WA. Emergency department presentation of pituitary apoplexy. American Journal of Emergency Medicine 200018 328-331. (doi:10.1016/S0735-6757(00)90130-X)

85 Tanriverdi F, Karaca Z, Oner A, Durak AC, Selcuklu A, Unluhizarci K \& Kelestimur F. Complete surgical resolution of bilateral total opthalmoplegia without visual field defect in an acromegalic patient presented with pituitary apoplexy. Endocrine Journal 200754 681-684. (doi:10.1507/endocrj.K07-008)

86 Arafah BM, Harrington JF, Madhoun ZT \& Selman WR. Improvement of pituitary function after surgical decompression for pituitary tumor apoplexy. Journal of Clinical Endocrinology and Metabolism 199071 323-328. (doi:10.1210/jcem-71-2-323)

87 Agrawal D \& Mahapatra AK. Pituitary apoplexy and inappropriate ADH secretion. Journal of Clinical Neuroscience 200310 260-261. (doi:10.1016/S0967-5868(03)00002-X)

88 Zayour DH, Selman WR \& Arafah BM. Extreme elevation of intrasellar pressure in patients with pituitary tumor apoplexy: relation to pituitary function. Journal of Clinical Endocrinology and Metabolism 200489 5649-5654. (doi:10.1210/jc.2004-0884)

89 Nielsen EH, Lindholm J, Bjerre P, Christiansen JS, Hagen C, Juul S, Jorgensen J, Kruse A \& Laurberg P. Frequent occurrence of pituitary apoplexy in patients with non-functioning pituitary adenoma. Clinical Endocrinology 200664 319-322. (doi:10.1111/j.1365-2265. 2006.02463.x)

90 Agrawal D \& Mahapatra AK. Visual outcome of blind eyes in pituitary apoplexy after transsphenoidal surgery: a series of 14 eyes. Surgical Neurology 200563 42-46. (doi:10.1016/j.surneu.2004.03.014)

91 Maccagnan P, Macedo CL, Kayath MJ, Nogueira RG \& Abucham J. Conservative management of pituitary apoplexy: a prospective study. Journal of Clinical Endocrinology and Metabolism 199580 2190-2197.

$92 \mathrm{Kim} \mathrm{SH}$, Lee KC \& Kim SH. Cranial nerve palsies accompanying pituitary tumour. Journal of Clinical Neuroscience 200714 1158-1162. (doi:10.1016/j.jocn.2006.07.016)

93 Onesti ST, Wisniewski T \& Post KD. Clinical versus subclinical pituitary apoplexy: presentation, surgical management, and outcome in 21 patients. Neurosurgery 199026 980-986. (doi:10.1227/00006123199006000-00010)

94 Banerjee C, Snelling B, Hanft S \& Komotar RJ. Bilateral cerebral infarction in the setting of pituitary apoplexy: a case presentation and literature review. Pituitary 2014

95 Sachdev Y, Gopal K, Garg VK \& Mongia SS. Pituitary apoplexy (spontaneous pituitary necrosis). Postgraduate Medical Journal 198157 289-293. (doi:10.1136/pgmj.57.667.289)

96 Tedd HM, Tuckett J, Arun C \& Dhar A. An unusual case of sudden onset headache due to pituitary apoplexy: a case report and review of the new UK guidelines. Journal of the Royal College of Physicians of Edinburgh 201242 119-123. (doi:10.4997/JRCPE.2012.206)

$97 \mathrm{Ni} \mathrm{CD} \mathrm{\&} \mathrm{Lambert} \mathrm{J.} \mathrm{Sudden} \mathrm{headache,} \mathrm{third} \mathrm{nerve} \mathrm{palsy} \mathrm{and} \mathrm{visual}$ deficit: thinking outside the subarachnoid haemorrhage box. Age and Ageing 201342 810-812. (doi:10.1093/ageing/aft088)

98 Wong SH, Das K \& Javadpour M. Pituitary apoplexy initially mistaken for bacterial meningitis. BMJ Case Reports 2013. (doi:10.1136/bcr-2013-009223)

99 Paisley AN \& Syed AA. Pituitary apoplexy masquerading as bacterial meningitis. Canadian Medical Association Journal 20121841812. (doi:10.1503/cmaj.120174)
100 Silvestrini M, Matteis M, Cupini LM, Troisi E, Bernardi G \& Floris R. Ophthalmoplegic migraine-like syndrome due to pituitary apoplexy. Headache 199434 484-486. (doi:10.1111/j.1526-4610.1994. hed3408484.x)

101 McFadzean RM, Doyle D, Rampling R, Teasdale E \& Teasdale G. Pituitary apoplexy and its effect on vision. Neurosurgery 199129 669-675. (doi:10.1227/00006123-199111000-00005)

102 Verrees M, Arafah BM \& Selman WR. Pituitary tumor apoplexy: characteristics, treatment, and outcomes. Neurosurgical Focus 2004 16 E6. (doi:10.3171/foc.2004.16.4.7)

103 Post MJ, David NJ, Glaser JS \& Safran A. Pituitary apoplexy: diagnosis by computed tomography. Radiology 1980134 665-670. (doi:10.1148/ radiology.134.3.7355215)

104 Freeman WD. Pituitary apoplexy. Neurocritical Care 20053 174-176. (doi:10.1385/NCC:3:2:174)

105 Bradley WG Jr. MR appearance of hemorrhage in the brain. Radiology 1993189 15-26. (doi:10.1148/radiology.189.1.8372185)

106 Piotin M, Tampieri D, Rufenacht DA, Mohr G, Garant M, Del CR, Robert F, Delavelle J \& Melanson D. The various MRI patterns of pituitary apoplexy. European Radiology 19999 918-923. (doi:10.1007/ s003300050767)

107 Arita K, Kurisu K, Tominaga A, Sugiyama K, Ikawa F, Yoshioka H, Sumida M, Kanou Y, Yajin K \& Ogawa R. Thickening of sphenoid sinus mucosa during the acute stage of pituitary apoplexy. Journal of Neurosurgery 200195 897-901. (doi:10.3171/jns.2001.95.5.0897)

108 Rajasekaran S, Vanderpump M, Baldeweg S, Drake W, Reddy N, Lanyon M, Markey A, Plant G, Powell M, Sinha S et al. UK guidelines for the management of pituitary apoplexy. Clinical Endocrinology 2011 74 9-20. (doi:10.1111/j.1365-2265.2010.03913.x)

109 Vicente A, Lecumberri B \& Galvez MA. Clinical practice guideline for the diagnosis and treatment of pituitary apoplexy. Endocrinología y nutrición 201360 582. (doi:10.1016/j.endonu.2013.04.013)

110 Epstein S, Pimstone BL, De Villiers JC \& Jackson WP. Pituitary apoplexy in five patients with pituitary tumours. BMJ 19712 267-270. (doi:10.1136/bmj.2.5756.267)

111 Chang CV, Felicio AC, Toscanini AC, Teixeira MJ \& Cunha-Neto MB. Pituitary tumor apoplexy. Arquivos de Neuro-Psiquiatria 200967 328-333. (doi:10.1590/S0004-282X2009000200033)

112 Reddy NL, Rajasekaran S, Han TS, Theodoraki A, Drake W, Vanderpump M, Baldeweg S \& Wass JA. An objective scoring tool in the management of patients with pituitary apoplexy. Clinical Endocrinology 201175 723. (doi:10.1111/j.1365-2265.2011.04081.x)

113 Jho DH, Biller BM, Agarwalla PK \& Swearingen B. Pituitary apoplexy: large surgical series with grading system. World Neurosurgery 201482 781-790. (doi:10.1016/j.wneu.2014.06.005)

114 Chuang CC, Chang CN, Wei KC, Liao CC, Hsu PW, Huang YC, Chen YL, Lai LJ \& Pai PC. Surgical treatment for severe visual compromised patients after pituitary apoplexy. Journal of Neuro-Oncology 200680 39-47. (doi:10.1007/s11060-006-9148-7)

115 Woo HJ, Hwang JH, Hwang SK \& Park YM. Clinical outcome of cranial neuropathy in patients with pituitary apoplexy. Journal of Korean Neurosurgical Society 201048 213-218. (doi:10.3340/jkns. 2010.48.3.213)

116 Muthukumar N, Rossette D, Soundaram M, Senthilbabu S \& Badrinarayanan T. Blindness following pituitary apoplexy: timing of surgery and neuro-ophthalmic outcome. Journal of Clinical Neuroscience 200815 873-879. (doi:10.1016/j.jocn.2007.08.010)

117 Fernandez Real JM, Villabona CM, Montana E, Acebes JJ, Ricart W, Sahun M, Gomez JM \& Soler J. Pituitary apoplexy: analysis of endocrine function in 17 cases. Medicina Clínica 199196 521-524.

118 Liu ZH, Chang CN, Pai PC, Wei KC, Jung SM, Chen NY \& Chuang CC. Clinical features and surgical outcome of clinical and subclinical pituitary apoplexy. Journal of Clinical Neuroscience 201017 694-699. (doi:10.1016/j.jocn.2009.11.012)

119 Pal A, Capatina C, Tenreiro AP, Guardiola PD, Byrne JV, Cudlip S, Karavitaki N \& Wass JA. Pituitary apoplexy in non-functioning 
pituitary adenomas: long term follow up is important because of significant numbers of tumour recurrences. Clinical Endocrinology 2011 75 501-504. (doi:10.1111/j.1365-2265.2011.04068.x)

120 Warwar RE, Bhullar SS, Pelstring RJ \& Fadell RJ. Sudden death from pituitary apoplexy in a patient presenting with an isolated sixth cranial nerve palsy. Journal of Neuro-Ophthalmology 200626 95-97. (doi:10.1097/01.wno.0000223270.01813.57)

121 Fraser LA, Lee D, Cooper P \& Van US. Remission of acromegaly after pituitary apoplexy: case report and review of literature. Endocrine Practice 200915 725-731. (doi:10.4158/EP09126.CRR)

122 Wichers M, Kristof RA, Springer W, Schramm J \& Klingmuller D. Pituitary apoplexy with spontaneous cure of acromegaly and its possible relation to Gd-DTPA-administration. Acta Neurochirurgica 1997139 992-994. (doi:10.1007/BF01411312)

123 Nishioka H, Haraoka J \& Miki T. Spontaneous remission of functioning pituitary adenomas without hypopituitarism following infarctive apoplexy: two case reports. Endocrine Journal $2005 \mathbf{5 2}$ 117-123. (doi:10.1507/endocrj.52.117)

124 Alarifi A, Alzahrani AS, Salam SA, Ahmed M \& Kanaan I. Repeated remissions of Cushing's disease due to recurrent infarctions of an ACTH-producing pituitary macroadenoma. Pituitary 20058 81-87. (doi:10.1007/s11102-005-2961-8)

125 Le NE, Abecassis JP, Bertagna X, Bonnin A \& Luton JP. Silent necrosis of a pituitary corticotroph adenoma revealed by timely magnetic resonance imaging: a cause of spontaneous remission of Cushing's disease. European Journal of Endocrinology 1994130 469-471. (doi:10.1530/ eje.0.1300469)

126 Kamiya Y, Jin-No Y, Tomita K, Suzuki T, Ban K, Sugiyama N, Mase M, Sakuma N \& Kimura G. Recurrence of Cushing's disease after longterm remission due to pituitary apoplexy. Endocrine Journal $2000 \mathbf{4 7}$ 793-797. (doi:10.1507/endocri.47.793)

127 Werner PL, Shah JH, Kukreja SC, Miller SM \& Williams GA. Recurrence of acromegaly after pituitary apoplexy. Journal of the American Medical Association 1982247 2816-2818. (doi:10.1001/jama.1982. 03320450050035)

128 Reddy R, Cudlip S, Byrne JV, Karavitaki N \& Wass JA. Can we ever stop imaging in surgically treated and radiotherapy-naive patients with non-functioning pituitary adenoma? European Journal of Endocrinology 2011165 739-744. (doi:10.1530/EJE-11-0566)

129 Acikgoz B, Cagavi F \& Hakki TI. Late recurrent bleeding after surgical treatment for pituitary apoplexy. Journal of Clinical Neuroscience 2004 11 555-559. (doi:10.1016/j.jocn.2003.07.006)

130 Wass JA \& Karavitaki N. Nonfunctioning pituitary adenomas: the Oxford experience. Nature Reviews. Endocrinology 20095 519-522. (doi:10.1038/nrendo.2009.147)

131 Wass JA, Reddy R \& Karavitaki N. The postoperative monitoring of nonfunctioning pituitary adenomas. Nature Reviews. Endocrinology 20117 431-434. (doi:10.1038/nrendo.2011.54)

Received 17 September 2014

Revised version received 22 November 2014

Accepted 1 December 2014 